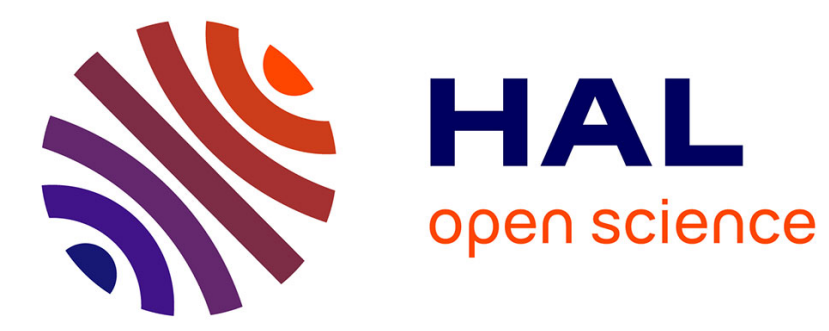

\title{
Pear breeding for Fireblight resistance. Program and first studies in France
}

Bernard Thibault

\section{To cite this version:}

Bernard Thibault. Pear breeding for Fireblight resistance. Program and first studies in France. Acta Horticulturae, 1981, 117, pp.63-69. hal-01601011

\section{HAL Id: hal-01601011 \\ https://hal.science/hal-01601011}

Submitted on 2 Jun 2020

HAL is a multi-disciplinary open access archive for the deposit and dissemination of scientific research documents, whether they are published or not. The documents may come from teaching and research institutions in France or abroad, or from public or private research centers.
L'archive ouverte pluridisciplinaire HAL, est destinée au dépôt et à la diffusion de documents scientifiques de niveau recherche, publiés ou non, émanant des établissements d'enseignement et de recherche français ou étrangers, des laboratoires publics ou privés.

\section{다(1)(2)}

Distributed under a Creative Commons Attribution - ShareAlikel 4.0 International 
B. Thibault

Station de Recherches d'Arboriculture Fruitière

Institut National de la Recherche Agronomique

Domaine de Bois 1'Abbé

Beaucouzé - 49000 Angers

France

\section{Abstract}

In 1975 a pear breeding program was started in order to obtain some pear varieties with a late picking date (30 to 50 days after Bon Chrétien Williams) and resistant or less susceptible to fireblight, caused by the bacteria E r w i n i a m y 1 o v o r a (Burr.) Winslow et al.

The first crosses were made between a parent of good quality, but susceptible (General Leclerc, Notaire Lepin) and a parent with good resistance to fireblight (Maxine, Mac, Dawn etc.).

For the last year the crosses are made only between resistant or less susceptible varieties mainly belonging to the genus Pyrus communis. A half diallel cross will be realised with 7 parents.

Testing the resistance is made either outside in the south-west of France (Dax) or in a greenhouse (Wageningen, the Netherlands) in the framework of the C.E.E. cooperation.

The first results are presented.

\section{Introduction}

Since the summer of 1978, when the first contaminations in pear orchards were noted in the south-west of France, the problem of substituting the common European varieties is raised with acuteness in our country.

Some varietal differences were seen, for instance Passe Crassane proved to be more susceptible than Bon Chrétien Williams. It is hoped that the disease will not establish in dryer areas like the south-east of France.

Two approaches of the problem seem justified, namely

- at short term to practice or develop cultural methods, including chemical control, in order to maintain the presently grown pear varieties in the best locations for pear production. The cultural and sanitation measures to be taken, however, increase the cost of production

- at long term to search for pear varieties sufficiently resistant to fireblight lowering the cost of production again and reducing the risk of spread of fireblight.

This paper deals with the last mentioned approach.

In the USA and Canada much effort has already been taken to search for varieties resistant or less susceptible to fireblight. The results obtained by screening the world's variety assortment and through breeding new less susceptible varieties are remarkable.

However, we have to recognize that no variety created for its resistance to fireblight is now commonly grown in commercial orchards. Despite its susceptibility the variety Bartlett (= Bon Chrétien Williams) 
accounts now for three quarters of the tonnage of pears produced in the U.S.A. (mainly for processing).

The efforts of pear breeders across the Atlantic are mainly directed towards varieties likely to replace Bartlett: same picking date, same taste, same uses.

In France and even in southern Europe the percentage of Bon Chrétien Williams of the total pear production is much lower (table 1).

Table 1 - Production of pears

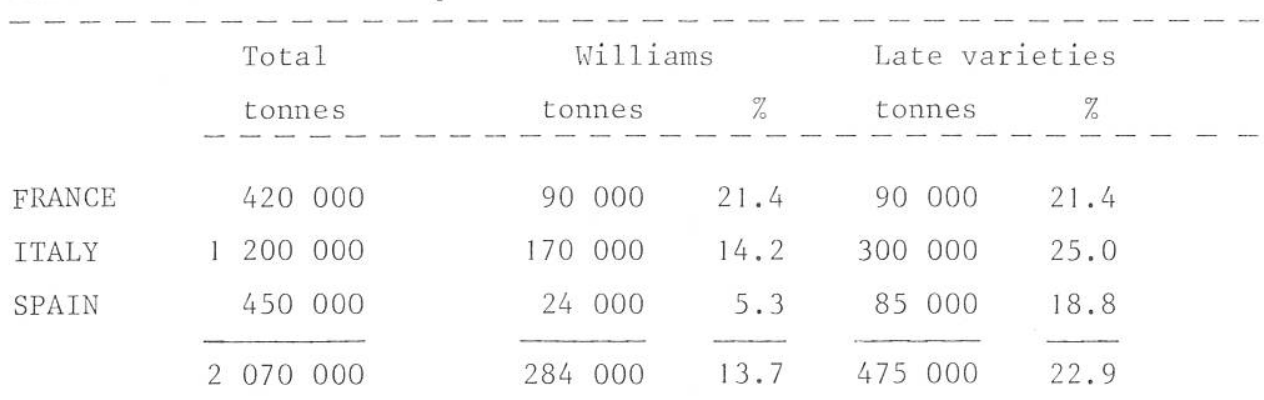

On the other hand the part of late maturing varieties accounts for 20 to $25 \%$ of the total production.

It therefore seemed important to start a breeding and selection program aiming at late maturing varieties with good keeping quality and resistance to fireblight.

2. Material and Methods

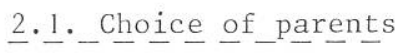

It is known that the susceptibility of different genotypes to fireblight is very variable according to physiological or climatic conditions.

Therefore about 50 European varieties and 20 American or Canadian new hybrids were colledted and planted in an experimental orchard located in Dax-area where fireblight was discovered in 1978. The pomological characteristics of these varieties and hybrids were well known in France through the introduction for many years in the INRA station at Angers.

What parents were available at the outset?:

- Some new varieties issued by U.S.D.A. such as Dawn, Magness, Moonglow or by the University of New Jersey such as Lee, Mac, Star or by Tennessee Station such as Mericourt. They all show, with a variable degree of resistance, some important defects about the habit of the tree, the productivity or the quality of the fruits.

- Some older varieties or chance seedlings having shown an interesting level of resistance and a fairly good quality: Beurre Capiaumont, Doyenne Gris, Duchesse d'Angoulême, Figue d'Alençon, Louise Bonne d'Avranches, Maxine, Pierre Corneille, Sirrine, Starking Delicious.

- Thanks to the courtesy of T. van der Zwet, Beltsville, U.S.A. and H. Quamme, Harrow, Canada a score of new hybrids showing good quality and good resistance could also be introduced. 
Table 2 shows a 1 ist of the different parents with their characteristics concerning the picking-date, the productivity, the taste and the level of resistance (noted in their country of origin).

\section{2 . Crosses carried out}

Table 3 sums up the different crosses which were made.

The first hybridizations began during the spring of 1975. The Fruit Laobratory of Beltsville agreed to inoculate the young seedlings under greenhouse conditions. It was a cross between General Leclerc, a new French variety, heavy bearer and with good quality but probably susceptible to fireblight and Starking Delicious, a non susceptible variety. The progeny included 150 seedlings.

In 1976 two progenies were made between Notaire Lepin, a susceptible variety but transmitting good quality to its offsprings, and two resistant varieties: Mac and Dawn. Around 220 hybrids were obtained for each cross.

After E r w i n a a m y 1 o v o r a was detected in pear orchards in the south-west of France, the forementioned progenies were planted in the spring of 1979 in an experimental orchard at Dax. Inoculations with E r.w $i \mathrm{n}$ i a a m y 1 o v o r a were carried out in June and July 1980.

During the spring of 1978, 5 other progenies were undertaken between Notaire Lepin and different gene sources for resistance: Dawn, Mac, Maxine, US 309 and US 62.563.44 for a total of 600 seedlings settled in Dax in the spring of 1980. They will be inoculated in June 1981 .

In april 1979, 16 progenies were carried out between Pierre Corneil-le, which showed no symptoms of fireblight under natural infection conditions in Harrow and various resistant varieties. Some of these progenies and others, made in 1980, were incorporated in a half diallel plan with 7 parents and 21 progenies (table 4). This could provide a better knowledge of the general as well as the specific abilities to transmit the resistance for these 7 parents.

\subsection{Assessment of the resistance}

Inoculation of seedlings produced in 1976 and 1978 was carried out in June at the top of a growing shoot, using a hypodermic syringe. Inoculations were made by J.P. Paulin, Phytobacteriology Station, Angers.

Next september the severity of fireblight injury in the shoots was measured. Three classes were used: less than $25 \%$ of the shoot length blighted, from $25 \%$ - $50 \%$ of shoot length blighted and more than $50 \%$ of shoot length blighted. The diseased part of the shoots were removed and new inoculations were made next year.

The seedlings produced in 1979 and 1980 are or will be tested for their resistance to fireblight in 3 different ways

- inoculations under greenhouse conditions in the Research Institute for Plant Protection, Wageningen, the Netherlands, thanks to the collaboration of H.P. Maas Geesteranus

- artificial inoculations after planting in an orchard at Dax in the south-west of France

- under natural infection conditions at Dunkerque in the north-west of France, where fireblight occurs since 1972 on hawthorns and where lower temperatures prevail.

The hybrids that will have shown some resistance will be grown until the end of their juvenile period and will be then artificially inocula- 
ted on flowers. Finally the resistant hybrids will be assessed for their productivity and the quality of their fruits.

\section{Results}

\subsection{Inoculations in the open}

The first results are about the crosses planted at Dax in the spring of 1979 and inoculated by needle in June 1980. Many plants did not show any symptoms. They will be inoculated again in 1981 .

48 plants out of 163 had a reaction in the cross Notaire Lepin $\mathrm{x}$ Dawn and 37 out of 187 in the cross Notaire Lepin x Mac. The repartition in the three classes mentioned above is shown in table 5 .

\subsection{Inoculations under greenhouse conditions}

All the seedlings inoculated at Beltsville were killed by fireblight. 1850 seedlings belonging to 11 crosses were inoculated in 1980 by H.P. Maas Geesteranus by cutting the top of young leaves in a bacterial suspension.

The results involving 1728 seedlings are shown in table 6 under three headings: very susceptible, dead; no symptoms; more or less clear symptoms such as:

- infection limited to the leaf but without reaching the stem

- shoot infection stopped with appearance of a new healthy shoot

- shoot bent without any necrosis.

Three gene sources delivered less than $70 \%$ very susceptible plants: US 62.574.13; Doyenne Gris and Duchesse d'Angoulême, the first one giving almost $24 \%$ plants without symptoms.

\section{Discussion}

Although the number of seedlings were rather limited and although the experiments are not yet completed some ideas may be highlighted:

- as far as inoculations in the open are concerned, it seems that Dawn has transmitted a better resistance rate on shoots than Mac;

- inoculations under greenhouse conditions resulted in more severe infection than those carried out in the open. It is, however, difficult to compare results from the outdoor and the greenhouse tests since different progenies were involved. The series inoculated in the open originated from crosses between 'susceptible' $\mathrm{x}$ 'resistant' varieties, whereas the series inoculated under greenhouse conditions originated from crosses between 'less susceptible' $\mathrm{x}$ 'less susceptible' varieties or 'less susceptible' $\mathrm{x}$ 'resistant' varieties.

In future a better comparison can be made as material from progenies, which have already been tested under greenhouse conditions, was planted outdoors at Dax and Dunkerque.

With respect to the methods used two other points can be brought forward:

- the heritability of resistance on flowers will be difficult to establish if a first screening is made on leaves or young shoots. In order not to bias results the inoculation on flowers should be made on whole progenies and not on already screened subjects.

- What is the value of the resistance of the plants that have shown a beginning of necrosis but where this necrosis has naturally stopped damaging only the leaf or a part of the shoot? Are they to be prefered to those without any symptoms but which could have escaped 
Table 2 - Characteristics of varieties and hybrids showing some resistance to fireblight

\begin{tabular}{|c|c|c|c|c|}
\hline------- & $\begin{array}{l}\text { Picking } \\
\text { date_(1) }\end{array}$ & $\begin{array}{l}\text { Productivity } \\
--(2)---\end{array}$ & $\begin{array}{l}\text { Quality } \\
--(\underline{3})--\end{array}$ & $\begin{array}{l}\text { Degree of } \\
\text { resistance }(4)\end{array}$ \\
\hline Dawn & +10 & 2 & 5 & $6-8$ \\
\hline Magness & +30 & 1 & 4 & $8-10$ \\
\hline Moonglow & +25 & 3 & 2 & $7-8$ \\
\hline Star & $=$ & 3 & 3 & 5 \\
\hline Mac & +20 & 2 & 3 & $7-8$ \\
\hline Lee & +20 & 3 & 1 & $1-2$ \\
\hline Mericourt & +30 & 3 & 2 & $7-8$ \\
\hline D. d'Angoulême & +40 & 3 & 3 & $7-8$ \\
\hline L. Bonne & +20 & 4 & 4 & 5 \\
\hline P. Corneille & +30 & 5 & 5 & 5 \\
\hline Maxine & +10 & 3 & 3 & $7-10$ \\
\hline Starking Del. & +10 & 3 & 3 & $7-8$ \\
\hline Sirrine & +10 & 3 & 4 & 5 \\
\hline B. Capiaumont & +20 & 5 & 3 & 7 \\
\hline Doyenne Gris & +50 & 4 & 3 & 7 \\
\hline Figue d'Alençon & +60 & 5 & 3 & 7 \\
\hline E1dorado & +50 & 3 & 3 & 6 \\
\hline Mich. 437 & +20 & 4 & 3 & 6 \\
\hline US 309 & +25 & 5 & 3 & $7-8$ \\
\hline HW 602 & -8 & $?$ & 4 & $8-9$ \\
\hline H $6831 / 1.12$ & +30 & $?$ & 4 & $7-8$ \\
\hline H. $6516 / 1037$ & +30 & $?$ & 3 & 10 \\
\hline US 62.563 .44 & +10 & 4 & 4 & 7 \\
\hline US 62.574 .13 & +15 & 3 & $2 / 3$ & 7 \\
\hline I11.13.B. 83 & +40 & 3 & 3 & $?$ \\
\hline H. $6720 / 1.001$ & $?$ & 4 & 2 & 10 \\
\hline
\end{tabular}

(1) Compared with Bon Chrétien Williams

(2) or (3) Noted on 5

(4) U.S.D.A. System 
Table 3 - Crosses made in Angers

Number of seeds

\begin{tabular}{|c|c|c|c|}
\hline 1975 & General Leclerc & x Starking Del. & 150 \\
\hline 1976 & Notaire Lepin & $\begin{array}{l}\text { x } \mathrm{Mac} \\
\text { x Dawn }\end{array}$ & $\begin{array}{l}220 \\
220\end{array}$ \\
\hline 1978 & Notaire Lepin & $\begin{array}{l}\text { x Mac } \\
x \text { Dawn } \\
x \text { Maxine } \\
x \text { US } 309 \\
x \text { US } 62.563 .44\end{array}$ & $\begin{array}{r}25 \\
350 \\
175 \\
25 \\
30\end{array}$ \\
\hline 1979 & Pierre Corneille & $\begin{array}{l}\text { x Mac } \\
\text { x Dawn } \\
\text { x Maxine } \\
\text { x Doyenne Gris } \\
\text { x B. Capiaumont } \\
\text { x D. d'Angoulême } \\
\text { x Figue d'Alençon } \\
\text { x Starking Delicious } \\
\text { x Sirrine } \\
\text { x HW 602 } \\
\text { x US 62.574.13 } \\
\text { x I11. 13.B.83 }\end{array}$ & $\begin{array}{r}350 \\
660 \\
160 \\
380 \\
50 \\
270 \\
500 \\
260 \\
590 \\
270 \\
370 \\
750\end{array}$ \\
\hline 1980 & $\begin{array}{l}30 \text { crosses with the } \\
\text { H } 6720 / 1.001 \\
\text { Michigan } 437 \\
\text { Eldorado }\end{array}$ & same parents, plus: & \\
\hline
\end{tabular}

Table 4 - Half-diallel crosses

Dawn (W x Seck) x W

$\mathrm{x}$ Comice

$\operatorname{Mac}(W \times J$. de Malines)

$\mathrm{x}$ NJ 1

13.B.83 (Comice $\mathrm{x}$

Farming) $x$ Maxine

$80 \quad 80$

Mich. 437 (W x Seck) x W

$80 \quad 80$

80

Figue d'Alençon

80

80

80

80

Doyenne Gris

80

80

81

80

81

Pierre Corneille

79

79

80

79

79

79

(1) this number indicates the year

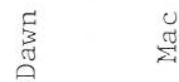
of the cross

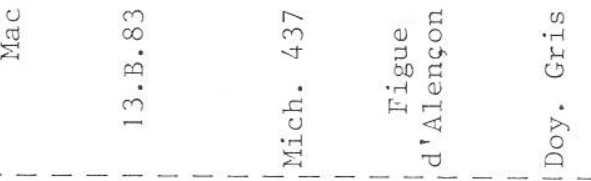


Table 5 - Results after inoculation in the open at Dax - 1980

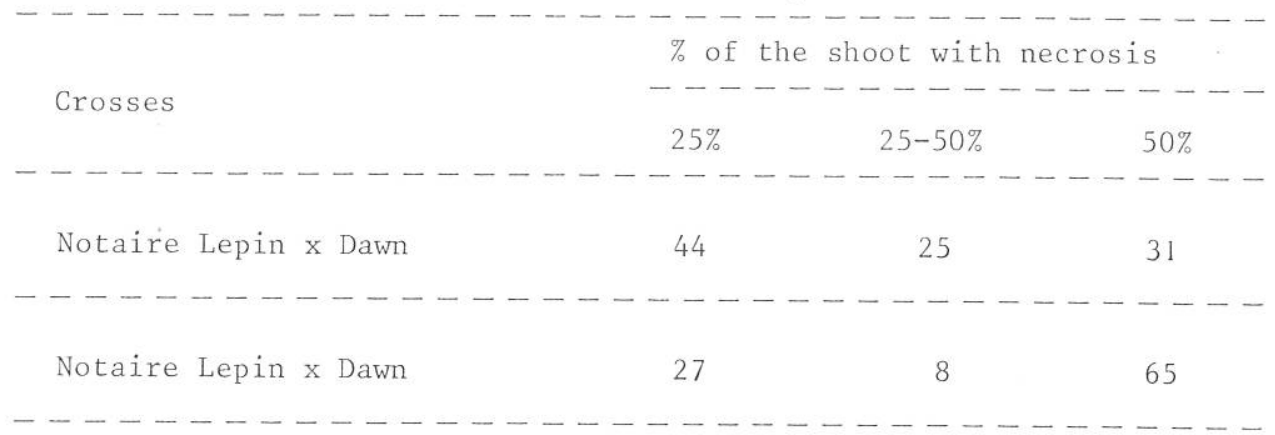

Table 6 - Results after inoculation under greenhouse conditions - 1980 Mother parent: Pierre Corneille

\begin{tabular}{|c|c|c|c|c|}
\hline Pollen & $\begin{array}{l}\text { Number of } \\
\text { plants }\end{array}$ & $\begin{array}{l}\% \\
\text { Very } \\
\text { susceptible }\end{array}$ & $\begin{array}{l}\text { of seedlin } \\
----- \\
\text { No } \\
\text { symptoms }\end{array}$ & $\begin{array}{l}\text { gs } \\
\text { Various delayed } \\
\text { symptoms }\end{array}$ \\
\hline Dawn & 290 & 78.27 & 5.86 & 15.86 \\
\hline US $\quad 62574.13$ & 92 & 61.95 & 23.91 & 14.13 \\
\hline Sirrine & 201 & 69.65 & 14.92 & 15.42 \\
\hline $13-B-93$ & 276 & 73.55 & 5.43 & 21.01 \\
\hline Figue d'Alençon & 244 & 85.65 & 3.69 & 10.65 \\
\hline Mac & 157 & 71.33 & 12.10 & 16.56 \\
\hline Maxine & 67 & 74.62 & 1.50 & 23.88 \\
\hline Starking Del. & 94 & 74.46 & 10.63 & 14,89 \\
\hline HW. 602 & 79 & 77.21 & 7.59 & 15.19 \\
\hline Doyenne Gris & 111 & 67.68 & 14.02 & 21.34 \\
\hline D. d'Angoulême & $\begin{array}{l}45 \\
---\ldots-\end{array}$ & $\begin{array}{l}64.44 \\
--\ldots-\ldots\end{array}$ & 17.77 & $\begin{array}{c}17.77 \\
---\ldots-\ldots\end{array}$ \\
\hline
\end{tabular}


